\title{
Pengaruh Pemberian ZPT BAP dan GA3 terhadap Pertumbuhan Tunas Ubi Jalar (Ipomea batatas L.) Varietas Cilembu secara In Vitro
}

\author{
The Effect of Giving BAP and GA3 Growth Regulatory Substances in the Growth of Sweet \\ Potatoes (Ipomea batatas L.) Cilembu Varieties In Vitro
}

\author{
Rudi Wardana ${ }^{\# 1}$, Roayatus Syafa'ah ${ }^{* 2}$, Jumiatun ${ }^{\# 3}$ \\ \#Jurusan Produksi Pertanian ,Politeknik Negeri Jember, Jln. Mastrip No. 164 Jember \\ ${ }^{1}$ rudi_wardana@polije.ac.id \\ 3 jumiatun@polije.ac.id \\ *Jurusan Produksi Pertanian ,Politeknik Negeri Jember, Jln. Mastrip No. 164 Jember \\ ${ }^{2}$ rudi_wardana@polije.ac.id
}

\begin{abstract}
ABSTRAK
Cilembu adalah ubi jalar yang memiliki rasa manis dan legit yang tidak diolah oleh ubi jenis lain. Cilembu memiliki kandungan karbohidrat, vitamin dan mineral yang tinggi. Oleh karena itu tanaman ini berpotensi sebagai pengganti beras dalam bentuk pangan alternatif. Permasalahan yang terjadi antara lain berbagai kendala, teknik budidaya serta kualitas bibit tanaman cilembu yang kurang baik. Oleh karena itu, perlu dilakukan peningkatan kualitas sentra produksi dengan meningkatkan kebutuhan bibit berkualitas dalam teknik kultur jaringan. Penelitian ini dilakukan dengan menambahkan konsentrasi BAP dan GA3 untuk merangsang pertumbuhan eksplan cilembu. Penelitian ini dilaksanakan pada bulan September 2019 sampai Februari 2020 di Laboratorium Kultur Jaringan Politeknik Negeri Jember. Rancangan percobaan disusun menggunakan rancangan acak lengkap faktorial dengan 2 faktor. Faktor pertama adalah konsentrasi BAP dengan 1 ppm; 1,5 ppm; 2 ppm. Faktor kedua adalah konsentrasi GA3 sebesar 0,1 ppm; 0,5 ppm; 1 ppm. Hasil penelitian menunjukkan penambahan GA3 dengan konsentrasi 0,5 pm berpengaruh terhadap keberadaan tunas yaitu 15 hari setelah tanam, sedangkan BAP 1 ppm berpengaruh terhadap jumlah akar yaitu 16 akar.
\end{abstract}

Kata Kunci-BAP, GA3, dan Cilembu

\begin{abstract}
Cilembu is a sweet potato that has a sweet and legit taste that's not prosessed by other types of sweet potatoes. Cilembu has a high carbohydrate, vitamin and mineral. Therefore this plant has the potential as a substitute for rice in alternative food forms. The problems happened of various constraints, cultivation techniques as well as poor quality seedlings of cilembu plants. Therefore, it is necessary to improve the quality of production centers by increasing the need for quality seedlings in tissue culture techniques. This research was conducted by adding BAP and GA3 concentrations to stimulate the growth of cilembu explants. This research was conducted in September 2019 until February 2020 at the Tissue Culture Laboratories State of Polytechnic Jember. The experimental design was arranged using factorial completely randomized design with 2 factors. The first factor is BAP concentration with 1 ppm; 1.5 ppm; 2 ppm. The second factor is the concentration of GA3 with 0.1 ppm; 0.5 ppm; 1 ppm. The results showed the addition of GA3 with a concentration of 0.5 pm has an effect on the presentness of the shoots, which is 15 days after planting, hile the BAP of 1 ppm affects the number of roots, which is 16 roots.
\end{abstract}

Keywords-BAP, GA3, and Cilembu 


\section{Introduction}

Ketidakstabilan pertambahan produksi ubi jalar di Negara Indonesia belum mencapai target. Menurut data dari Badan Pusat Statistik [1], perkembangan produktivitas ubi jala di daerah Jawa Timur adalah 23 ton/ha. Meskipun pada tahun 2015 rata-rata produktivitas mencapai 21 ton/ha. Dibandingkan dengan Jawa barat yang mecapai 400 ton tahun 2014, kegiatan usaha tani masih tergolong rendah.

Peningkatkan produksi cilembu dapat dilakukan melalui intensifikasi menggunakan varietas unggul. Usaha peningkatan tersebut dilakukan dengan meningkatkan kebutuhan bibit unggul yang berkualitas [2].

Usaha yang dapat dilakukan untuk memperoleh bibit unggul yang seragam, bebas hama, dan penyakit dalam waktu singkat dan cepat dapat dilakukan melalui kultur jarangan atau in vitro [3]. Salah satu ZPT yang digunakan untuk menginduksi tunas yaitu BAP dan GA3. Kombinasi keduanya memiliki pengaruh nyata terhadap pertumbuhan tunas.

\section{Method}

Penelitian ini dilakukan pada bulan September 2019 sampai Februari 2020 di Laboratorium Kultur Jaringan, Politeknik Negeri Jember.Penelitian ini mengenai pengaruh pemberian ZPT BAP dan GA3 terhadap pertumbuhan tunas ubi jalar (Ipomea batatas L.) varietas cilembu secara in vitro.

Bahan-bahan yang digunakan untuk penelitian ini yaitu stek Ubi Jalar Cilembu, larutanstok A sampai $\mathrm{H}$, alkohol $96 \%$ dan $70 \%$, bakterisida Agrepht 30 yaitu 4 gr, fungisida Benlox 4 gr, tween 10 tetes, $\mathrm{NaOCl} 10 \%$ dan $\mathrm{NaOCl} 5 \%$, adsorbic acid, larutan, ZPT GA3, ZPT BAP.

Penelitian ini menggunakan RAL yang terdiri dari 2 faktor yaitu BAP (A) : 1, 1,5, 2 ppm dan GA3 (B) : 0,1, 0,5, 1 ppm, 9 kombinasi perlakuan (A1B1, A1B2, A1B3, A2B1, A2B2, A2B3, A3B1, A3B2, A3B3) dan 4 ulangan.Pada 1 ulangan terdapat 1 botol sehingga diperoleh 36 unit percobaan. Masing-masing botol ditanami satu eksplan.

\section{Discussion}

\subsection{Kedinian Tunas}

Kedinian tunas adalah waktu kemunculan tunas yang dibutuhkan eksplan untuk membentuk tunas pertama kali. Biasanya ditandai dengan adanya tonjolan hijau yang terletak di ujung atau ruas tunas.

Table 1. Uji DMRT 5\% Penambahan GA3 Terhadap Parameter Kedinian Tunas (HST)

\begin{tabular}{|c|c|c|c|}
\hline $\begin{array}{l}\text { Notasi } \\
\text { Notation }\end{array}$ & $\begin{array}{l}\text { Perlakuan } \\
\text { Treatments }\end{array}$ & $\begin{array}{l}\text { Rerata } \\
\text { Average }\end{array}$ & $\begin{array}{l}\text { Nilai DMRT } \\
5 \% \\
\text { DMRT 5\% } \\
\text { Value }\end{array}$ \\
\hline B2 & $0,5 \mathrm{ppm}$ & $15,00 \mathrm{a}$ & 0,80 \\
\hline B1 & $0,1 \mathrm{ppm}$ & $19,00 \mathrm{~b}$ & 0,84 \\
\hline B3 & $1 \mathrm{ppm}$ & $19,67 b$ & 0,87 \\
\hline
\end{tabular}

Keterangan = rerata yang diikuti dengan huruf yang sama di atasnya menunjukkan hasil tersebut tidak berbeda nyata pada uji DMRT 5\%.

Berdasarkan Tabel 1. penambahan ZPT GA3 dengan Konsentrasi B2 (0,5 ppm) dapat menunjukkan pembentukan tunas tercepat yaitu $15,00 \mathrm{HST}$ ( \pm 15 hari) yang mampu menginduksi tunas secara optimal. Respon pemberian GA3 pada konsentrasi yang sesuai dapat mempercepat terbentuknya tunas. GA3 berfungsi dalam pemanjangan tunas tanaman sehingga perpanjangan tunas itu disebabkan giberelin mampu menginduksi pemanjangan ruas dan hal ini sesuai dengan pendapat Zulkarnain [4]. Pemberian konsentrasi 0,5 ppm GA3 telah menunjukkan hasil optimal dalam waktu kemunculan tunas secara invitro dibandingkan konsentrasi GA3 0,1 ppm dan GA3 1 ppm butuh waktu untuk memunculkan tunas lebih lama pada hari ke 19. Hal ini membuktikan pemberian konsentrasi yang tepat dapat mempercepat induksi mata tunas ubi cilembu. Selain itu, tahapan sterilisasi yang benar juga dapat mempengaruhi keberhasilan penelitian ini.

Kombinasi antara ZPT BAP dan GA3 memberikan hasil berbeda tidak nyata, karena konsentrasi yang diberikan belum sesuai untuk parameter kedinian tunas. Dalam pembentukan tunas respon tanaman akan berbeda-beda 
tergantung dengan jenis eksplan dan media yang digunakan.

\subsection{Jumlah Tunas}

Parameter jumlah tunas di amati dengan melihat tumbuhnya tunas aksilar yang muncul dan di amati di akhir pengamatan.

Table 2. Hasil Analisa Sidik Ragam Jumlah Tunas

\begin{tabular}{|c|c|c|c|c|c|}
\hline \multirow{2}{*}{$\begin{array}{l}\text { Jumlah } \\
\text { Tunas } \\
\text { Keragaman }\end{array}$} & \multirow{2}{*}{ DB } & \multirow{2}{*}{$\begin{array}{c}F \\
\text { Hitung }\end{array}$} & \multirow{2}{*}{ Notasi } & \multicolumn{2}{|c|}{ F Tabel } \\
\hline & & & & $5 \%$ & $1 \%$ \\
\hline Perlakuan & 8 & 1,43 & ns & 2,22 & 3,07 \\
\hline Faktor A & 2 & 1,20 & ns & 3,27 & 5,27 \\
\hline Faktor B & 2 & 2,10 & ns & 3,27 & 5,27 \\
\hline Interaksi & 4 & 1,20 & ns & 2,64 & 3,91 \\
\hline KK & & 27,39 & & & \\
\hline
\end{tabular}

Keterangan $=\mathrm{ns}:($ non significant $)$ berbeda tidak nyata Note $=$ ns : non Significant

Tabel 2. di atas menunjukkan hasil yang didapat berbeda tidak nyata, hal ini memungkinkan karena perbandingan antara pemberian konsentrasi BAP dan GA3 yang diberikan masih kurang tepat sehingga hasil yang tidak diperolehhasil yang nyata untuk jumlah tunas. Pernyataan yang sesuai dengan Ramesh dan Ramassamy [5] yang menyatakan bahwa kemunculan jumlah tunas dapat diduga karena pengaruh dari tinggi tanaman, dengan demikian tunas yang muncul dalam botol sedikit maka tanaman akan semakin tinggi. Yang disebabkan karena dalam pembentukan calon tunas yang akan digunakan dalam pemanjangan tunas lainnya memerlukan energi.

Menurut Wicaksono, dkk. [6] menyatakan bahwa morfogenesis jaringan dipengaruhi oleh keseimbangan interaksi zat pengatur tumbuh yang ditambahkan dari luar (eksogen) dan hormon tumbuhyang dihasilkan sel itu sendiri. Andaryani [7] juga menyatakan bahwa, pertumbuhan tunas ditentukan oleh ZPT eksogen yang diberikan ke dalam media dan perimbangannya dengan ZPT endogen yang terdapat pada eksplan.

\subsection{Kedinian Akar}

Kedinian akar dihitung pada saat munculnya akar dari hari pertama setelah tanam yang ditandai dengan adanya tonjolan putih yang muncul pada eksplan atau serabut putih akar dan dapat dilihat dari bagian bawah media dan dinyatakan dalam satuan hari (HST).

Table 3. Hasil Uji Lanjut DMRT 5\% Interaksi Perlakuan Parameter Kedinian Akar (HST)

\begin{tabular}{lll}
\hline Perlakuan & Rata-Rata & $\begin{array}{l}\text { Nilai } \\
\text { DMRT }\end{array}$ \\
\hline A2B2 & $5,50 \mathrm{a}$ & 0,67 \\
A1B1 & $5,75 \mathrm{ab}$ & 0,70 \\
A3B2 & $6,25 \mathrm{bc}$ & 0,72 \\
A3B3 & $6,50 \mathrm{~cd}$ & 0,73 \\
A1B3 & $6,75 \mathrm{~cd}$ & 0,74 \\
A3B1 & $6,75 \mathrm{~cd}$ & 0,75 \\
A1B2 & $7,00 \mathrm{de}$ & 0,76 \\
A2B1 & $7,50 \mathrm{e}$ & 0,77 \\
A2B3 & $7,50 \mathrm{e}$ & 0,77 \\
\hline
\end{tabular}

Keterangan = rerata yang diikuti dengan huruf yang sama di atasnya menunjukkan hasil tersebut tidak berbeda nyata padauji DMRT 5\%.

Berdasarkan Tabel 3. di atas menunjukkan interaksi ZPT BAP dengan GA3 berbeda tidak nyata antara perlakuan satu dan lainnya. Tetapi, untuk perlakuan yang lebih efisien dapat menggunakan konsentrasi yang terkecil yaitu A1B1 (1 ppm BAP + 0,1 ppm GA3) dimana perlakuan tersebut mampu menginduksi akar \pm 5,57 HST berdasarkan analisa sidik ragam terdapat interaksi dari kedua faktor yaitu ZPT BAP dan GA3. BAP tergolong kedalam ZPT golongan sitokinin (BAP) yang berfungsi dalam mendorong proses pembelahan sel. Untuk menaikkan laju sintesa protein diikuti dengan aktifnya sitokinin dan enzim merupakan protein pembangun sel sehingga terbentuklah sel-sel baru yang pada akhirnya terdiferensiasi menjadi organ tertentu [8].

Menurut George dan Sherrington [9] penambahan GA3 pada media bertujuan untuk menstimulus terbentuknya hormon auksin endogen yang dapat menginduksi eksplan. 
Semakin meningkat konsentrasi BAP dengan konsentrasi GA3 yang lebih rendah, maka akan mempercepat munculnya akar ataupun sebaliknya. Pemberian BAP dan GA3 harus pada konsentrasi yang sesuai agar kebutuhan eksplan mata tunas terpenuhi.

\subsection{Jumlah Akar}

Table 4. Uji DMRT 5\% Penambahan ZPT BAP Terhadap Parameter Jumlah Akar.

\begin{tabular}{|c|c|c|c|}
\hline $\begin{array}{l}\text { Notasi } \\
\text { Notation }\end{array}$ & $\begin{array}{l}\text { Perlakuan } \\
\text { Treatments }\end{array}$ & $\begin{array}{l}\text { Rerata } \\
\text { Average }\end{array}$ & $\begin{array}{l}\text { Nilai DMRT } \\
5 \% \\
\text { DMRT 5\% } \\
\text { value }\end{array}$ \\
\hline $\mathrm{A} 2$ & $1,5 \mathrm{ppm}$ & $4,33 \mathrm{a}$ & 1,95 \\
\hline A3 & $2 \mathrm{ppm}$ & $8,00 \mathrm{~b}$ & 2,05 \\
\hline A1 & $1 \mathrm{ppm}$ & $16,00 \mathrm{c}$ & 2,11 \\
\hline
\end{tabular}

Keterangan $=$ rerata yang diikutidengan huruf yangsama di atasnya menunjukkanhasil tersebut tidakberbeda nyata padauji DMRT 5\%.

Berdasarkan hasil analisis pada Tabel 4. menunjukkan bahwa penambahan ZPT BAP dengan Konsentrasi 1 ppm (A1) mampu menginduksi terbentuknya akar paling banyak dengan rata-rata yaitu 16,00 . Hal ini diduga karena sitokinin mampu berkolaborasi secara sinergis dengan auksin endogen dalam memacu regenerasi dan perkembangan sel.

Zulkarnain [4] mengatakan fungsi akar sebagai alat untuk menyerap nutrisi dan unsur hara dan untuk menopang tubuh dari tanaman. Respon ZPT BAP berhhubungan dengan konsentrasi yang diberikan. Hormon auksin di dalam tanaman berfungsi dalam pembesaran akar, sehingga ZPT BAP bersinergi dengan auksin endogen untuk membentuk akar dengan konsentrasi sitokinin yang sesuai.

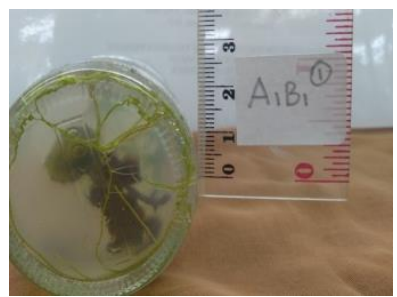

Figure 1. Planlet dengan jumlah akar terbanyak

\section{Conclusion}

\subsection{Penambahan ZPT GA3 dengan} konsentrasi 0,5 ppm berpengaruh terhadap terhadap kedinian tunas yaitu 15,00 HST.

4.2. Penambahan ZPT BAP berpengaruh nyata pada jumlah akar yaitu sebanyak 16 akar pada konsentrasi 1 ppm, sedangkan pada parameter kedinian tunas, jumlah tunas dan kedinian akar tidak berbeda nyata.

4.3. Kombinasi penambahan ZPT BAP dan GA3 berpengaruh tidak nyata terhadap kedinian tunas, jumlah tunas kedinian akar dan jumlah akar.

\section{Acknowledgement}

Terimakasih kepada Laboratorium Kultur Jaringan Politeknik Negeri Jember yang telah memfasilitasi dalam penelitian ini.

\section{References}

[1] Badan Pusat Statistik. 2016. Produksi Ubi Jalar Menurut Provinsi. http://www.bps.go.id/ [8 Agustus 2019].

[2] Sasongko, L. A. 2009. Perkembangan Ubi Jalar dan peluang pengembangannya untuk Mendukung Progra Percepatan Diversifikasi Konsumsi Pangan di Jawa Tengah. Wattimena, G. A. 2006. Prospek Plasma Nutfah Kentang Dalam Mendukung Swasembada Benih Kentang di Indonesia. Pusat Penelitian Sumber Daya Hayati Dan Bioteknologi (PPSHB) IPB Dan Jurusan Agrohorti, Agricultural Faculty. IPB, (April), 2-5.

[3] Damayanti, F. 2006. Pembentukan Beberapa Hibrida Anggrek Serta Pengaruh Beberapa Media Perkecambahan DanDamayanti, F. 2006. Pembentukan Beberapa Hibrida Ang Media Perbanyakan Cepat Secara In Vitro Pada Beberapa Anggrek Hibrida. Laproan Akhir Program Hibah Kompetisi. Universitas Padjajaran. Bandung.

[4] Zulkarnain,. 2009. kultur jaringan tanaman: solusi perbanyakan tanaman budi daya. Bumi Aksara.

[5] Ramesh, Y., and V. Ramassamy. 2014. Effect of gelling agents in in vitro multiplication of banana var. Poovan. Int. J. Advanced Bio.research 4(3): 308311

[6] Wicaksono, Nurmala, Irwan dan Putri. 2016. Pengaruh Pemberian gibberellin dan sitokinin pada konsentrasi yang berbeda terhadap pertumbuhan dan hasil gandum (Triticum aestivum L.) di dataran medium Jatinangor (T. Jurnal Kultivasi, 15(1), 52-58.

[7] Andaryani Setianingrum. 2010. Kajian Penggunaan Berbagai Konsentrasi BAP dan 2,4-D Terhadap 
Pengaruh Induksi Kalus Jarak Pagar (Jatrop hacuras L.) Secara In Vitro, Skripsi, Universitas Negeri Surakarta, Surakarta

[8] Salisbury, F. B and Ross, C. W. 1995. Fisiologi Tumbuhan. Jilid 4. ITB. Bandung
[9] George, E.F. and Sherrington. 1984. Plant Propagation By Tissue Culture. Exegtics Limited. England. P: 309. 